\title{
Banking Supervision - Conceptual Model of Banking Stress Test
}

\author{
Ioan VIORICA ${ }^{\star}$, Costinela FORTEA ${ }^{\star}$
}

\begin{tabular}{l}
\hline \multicolumn{1}{c}{ A R T I C L E I N F O } \\
\hline Article history: \\
Accepted January 2019 \\
Available online April 2019 \\
\hline JEL Classification \\
G21 \\
Keywords: \\
Banking supervision, Systemic risk, \\
Stress tests, Stability
\end{tabular}

\begin{abstract}
A B S T R A C T
This paper brings attention to banking supervision through some specific indicators to the banking system. The main purpose of prudential supervision is to maintain stability and confidence in the banking system. The stress test is a way of assessing the financial situation of a banking corporation in the event of severe risk events that may affect the volume of capital, financial performance and its existence. So we analyzed the evolution of the banking system as well as the main indicators of the banking system. The main objective of the systemic resistance test is to investigate exposures that could generate endemic effects in the banking sector.
\end{abstract}

(C) 2019 EAI. All rights reserved.

\section{Introduction}

Banking oversight illustrates an integral part of a process that involves determining a legal framework for the banking sector, indicating regulatory and supervisory authorities, defining the factors and criteria for granting operating authorizations, and introducing legislation that reduces the level of risk that banks are allowed to and to assume it, to establish a framework for prudential reporting, on-site supervision and performance of these activities, followed by desk analyzes. At international level, banking supervision is currently carried out on two levels: at the level of the banks and at the level of the supervisory authorities.

Banking supervision is a distinct way used in the banking field to verify the prudential indicators of the National Bank of Romania, of credit institutions authorized to operate.

Banking supervision is of a permanent nature, credit institutions being monitored throughout their operations as to how they evolve and meet the criteria of prudence and banking performance.

The main purpose of prudential supervision is to maintain stability and confidence in the banking system.

Prudential supervision of banking companies was carried out by the National Bank on the basis of periodical reports of commercial banks, as well as on-site inspections, which reflect the most complex way of supervision. On the basis of the assessments and verification carried out, the National Bank of Romania as a supervisory authority may provide recommendations to the credit institution in order to take appropriate measures to optimize the management framework, implementation processes and strategies, to ensure adequate systematization of the business, or to restore its financial situation, as well as in the event of a deterioration of its pride and financial indicators. Banking companies have the obligation to communicate to the National Bank of Romania the measures taken within the time limits set by the Bank.

According to the provisions of art. 2 paragraph 2 letter b) of the Law no.312 / 2004 on the Statute of the National Bank of Romania, as amended and supplemented, the central bank ensures the authorization, prudential regulation and supervision of credit institutions, promotion and monitoring the smooth functioning of payment systems to ensure financial stability.

The main purpose of a supervisory authority is to prevent systemic risk through promoting effective oversight that guarantee the stability and sustainability of the entire banking system. In order to achieve this, the National Bank of Romania uses stress tests as well as other tools and approaches.

Banks have often begun to rely on econometric models to manage risks, regardless of their nature: credit risk, market risk, liquidity risk or operational risk.

The notion of banking resistance test refers to a series of techniques that allow assessment of the capacity and the assessment of the vulnerabilities of the banking system to incorporate shocks in situations of exceptional but probable events. The Banking Strength Test combines macroeconomic data 
with prudential information through a systemic approach that measures the impact of shocks on financial stability.

The main objective of the systemic resistance test is to investigate exposures that could generate endemic effects in the banking sector.

Stress test indicates an evaluation of the financial situation of a banking company, and in case of severe risk events that may affect the amount of capital, financial performance and its existence. Macroeconomic Stress Testing Models used by the National Bank of Romania are oversight tools at both micro-prudential and macro-prudential levels that allow the assessment of the simultaneous impact of macroeconomic shocks on the solvency of credit institutions using various macroeconomic risk factors. Using these models allows estimating the cost of re-capitalization for each credit institution.

Table 1. Evolution of the banking system in Romania

\begin{tabular}{|lccc|}
\hline & 2015 & 2016 & 2017 \\
Number of credit institutions & 36 & 37 & 35 \\
Number of banks with majority private capital & 34 & 35 & 33 \\
$\begin{array}{l}\text { Number of banks with majority foreign capital, out } \\
\text { of which: }\end{array}$ & 30 & 32 & 33 \\
$\begin{array}{l}\text { - branches of foreign banks } \\
\text { The share of the first five banks in total assets (\%) }\end{array}$ & 7 & 8 & 7 \\
$\begin{array}{l}\text { The share of top five banks in total credit to the } \\
\text { private sector (\%) }\end{array}$ & 58,3 & 59,1 & 58,8 \\
$\begin{array}{l}\text { The share of the first five banks in the total } \\
\text { deposits attracted from the private sector (\%) }\end{array}$ & 62,4 & 60,7 & 57,9 \\
$\begin{array}{l}\text { Herfindahl-Hirschmann Index, assets (points) } \\
\text { Herfindahl-Hirschmann Index, credit (points) }\end{array}$ & 876 & 904 & 915 \\
Herfindahl-Hirschmann Index, deposits (points) & 960 & 866 & 874 \\
\hline
\end{tabular}

Source: National Bank of Romania- BNR-

As a result of the analysis of the above data, we can conclude that there is a high diversity of the majority capital in the country of origin and the financing is mainly ensured by attracting retail deposits.

In order to avoid consequences for financial stability, the National Bank of Romania proposed to credit institutions to take proactive measures to identify losses by covering non-performing loans with provisions. At the same time, the introduction of macro-prudential measures in imposing higher capital conditions helped to increase their ability to cope with adverse macroeconomic developments as stress testing exercises.

Table 2. The main indicators of the banking system analysis

\begin{tabular}{|lllll|}
\hline Indicator name & 2015 & 2016 & 2017 & sept. \\
& & & & 2018 \\
Total own funds rate & 19,2 & 19,7 & 20,0 & 20,07 \\
Tier 1 own funds rate & 16,7 & 17,5 & 18,0 & 17,8 \\
Rate of own funds level 1 base & 16,7 & 17,5 & 18,0 & 17,8 \\
The lever effect & 8,2 & 8,9 & 8,9 & 9,0 \\
Rate of non-performing loans & 13,5 & 9,6 & 6,4 & 5,5 \\
ROE & 11,8 & 10,4 & 12,5 & 15,6 \\
The degree of provisioning of bad loans & 57,7 & 56,3 & 57,6 & 57,5 \\
\hline
\end{tabular}

Source: National Bank of Romania-BNR-

Positive trends shown in Table 2 are accompanied by a number of systemic risk on financial stability.

According to Table 3, no severe systemic risks are identified, there are only three systemic highrisk estimated at a high level, namely: the risk of deterioration of investor confidence in emerging economies, the risk associated with uncertainties about the economic developments in the EU and the default risk of loans contracted by the sector NGOs. The risk regarding straining internal macroeconomic equilibrium is assessed as having a moderate intensity and the real estate market is at a low level. The financial vulnerabilities in terms of financial stability in Romania are caused by: the demographic problem accentuated by the intensification of the migration phenomenon in recent years as well as the maintenance of a negative population growth, low discipline in the payment of savings and vulnerabilities 
in the balance sheet of firms, potential for financial stability and the low level of financial intermediation being maintained at low levels below those recorded at European level.

Table 3. Risk Map to Financial Stability in Romania

\begin{tabular}{|l|l|}
\hline & $\begin{array}{l}\text { Deteriorating investor confidence in emerging economies } \\
\text { situation in the euro area }\end{array}$ \\
\hline & Risk of non-payment of credits contracted by the non-government sector \\
\hline
\end{tabular}

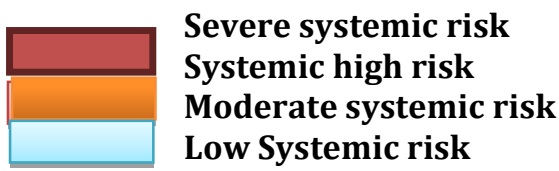

Note: The color indicates the intensity of the risk. The arrows indicate the risk perspective in the next period. Source: National Bank of Romania-BNR-

The stress tests of credit institutions' capital are based on scenarios describing the possible evolutions of the main macroeconomic variables: economic growth, inflation rate, unemployment rate, exchange rate, interest rates applied on the interbank market, risk as well as real estate prices. These exercises take into account several conditions: assessing operational profit according to scenarios, recording the impact of scenarios on adjustments for depreciation of financial assets and the effect on bank prudence indicators.

The most recent stress-testing exercise of credit institutions' solvency is conducted over a threeyear period and is made up of two macroeconomic scenarios: a baseline scenario and an adverse scenario.

The baseline scenario implies a likely change in the macroeconomic variables, and implies: a positive economic growth of $10.9 \%$ over the three analyzed years 2018-2020 but with a declining trend (from $4.4 \%$ at the end of 2018 up to $2.7 \%$ at the end of the period), a rate of CPI inflation, the value of which remains constant over the entire period under review, an unemployment rate that is around $5.2 \%$ at the end of the forecasting period, and residential property prices indicates an increasing trend, estimated at $20.4 \%$ by the end of the analysis period.

The adverse scenario implies: cumulative economic growth of $-1 \%$ by the end of the analyzed period, a cumulative CPI inflation rate of $0.1 \%$ at the end of 2020 , a $4.4 \%$ national currency depreciation compared to the baseline scenario, rising unemployment to $6.1 \%$ by the end of 2020 , housing and commercial property price developments, and a rise in long-term interest rates to $6.7 \%$ at the end of the period.

According to the CNSM Recommendation no. R / 7/2018 regarding the capital damper for systemic risk in Romania takes into account the structural dysfunction of the systemic risk, namely the risk distribution in the financial system. The main purpose of this damper is to strengthen the financial system's resilience and its sub-assemblies to the shocks caused by changes in accounting standards or legislation, the effects of the real economy, and the overspending of the financial system relative to the size of the economy, and the innovation process.

The motivation for introducing the capital damper for systemic risk is circumscribed to the following two perspectives: ensuring adequate credit risk management from a macro-prudential perspective due to the possibility of returning bad loans to an upward trend and maintaining financial stability if the strain on internal macroeconomic balances and regional and global uncertainties will persist. 
Table 4. List of systemic banks and dampers applicable in 2019

\begin{tabular}{|c|c|c|c|}
\hline Credit institution & $\begin{array}{c}\text { The score obtained in the } \\
\text { calculation of mandatory } \\
\text { indicators, according to } \\
\text { the methodology } \\
\text { harmonized with EBA } \\
\text { guide (basis points) }\end{array}$ & $\begin{array}{c}\text { Requirement to maintain } \\
\text { the capital damper for } \\
\text { systemic institutions } \\
\text { applicable from } 1 \\
\text { January 2019 (\% of total } \\
\text { exposure to risk) }\end{array}$ & $\begin{array}{c}\text { The level at which the } \\
\text { capital damper for } \\
\text { systemic institutions } \\
\text { applies }\end{array}$ \\
\hline $\begin{array}{c}\text { Transilvania S.A } \\
\text { Bank }\end{array}$ & 1621 & $2 \%$ & Consolidated \\
\hline $\begin{array}{c}\text { UniCredit Bank S.A } \\
\text { Banca Comercială } \\
\text { Română S.A }\end{array}$ & 1526 & $1 \%$ & Consolidated \\
\hline $\begin{array}{c}\text { BRD - Groupe } \\
\text { Societe Generale } \\
\text { S.A }\end{array}$ & 1391 & $2 \%$ & Consolidated \\
\hline $\begin{array}{c}\text { Raiffeisen Bank } \\
\text { S.A }\end{array}$ & 1164 & $1 \%$ & Consolidated \\
\hline $\begin{array}{c}\text { Alpha Bank } \\
\text { România S.A }\end{array}$ & 1001 & $2 \%$ & Consolidated \\
\hline CEC Bank S.A & 444 & $1 \%$ & Individual \\
\hline OTP Bank S.A & 332 & $1,5 \%$ & Individual \\
\hline
\end{tabular}

Starting January 1, 2019, the National Bank of Romania will constrain a capital damper for other systemically important institutions on a consolidated or individual basis for all credit institutions recognized as having a systemic character based on reported data, such as: $2 \%$ for Banca Comercială Română SA (consolidated level), 2\% for Raiffeisen Bank SA (consolidated level), 1.5\% for OTP Bank SA (consolidated level), 2\% for CEC Bank SA (individual level), 2\% for Transilvania SA Bank (consolidated), 1\% for Alpha Bank Romania SA (individual level), 1\% for BRD-Groupe Societe Generale SA (consolidated level) and 1\% for UniCredit Bank (consolidated level).

Damper aims to develop the banking sector resilience to potential losses induced by excessive credit growth. It is formed during the excessive credit growth period and can be released in the contraction phase for the purpose of absorbing losses.

The damper level shall be calibrated to $0 \%, 1 \%$ and $2 \%$, based on the 12 -month average of the non-performing loans ratio and provisioning.

Currently, total debt continues to remain below the alert level was therefore not necessary to establish a damper cyclical rate greater than $0 \%$.

\section{References}

1. Anghelache,C.Romania 2017.Starea economica la un deceniu de la aderare,Ed.Economica Bucuresti 2017

2. Căpraru B.- Activitate bancară: Sisteme, oprațiuni și practici, Editura C.H.Beck, București, 2010.

3. Dănilă N.- Management bancar.Fundamente și orientări, Editura Economică, București,2000

4. Trenca I.,Mutu S.- Managementul riscurilor bancare, Editura Casa Cărții de Stiință,Cluj-Napoca, 2012

5. Basno C., Dardac N. - Management bancar, Editura economică, București, 2002;

6. Virgil Andronache,"Banca si operatiunile comerciale-Spete si solutii practice in raporturile dintre client si banca".Ed.Universitara, Bucuresti, 2006;

7. Catalin Davidescu, Supravegherea bancara in Romania,Colectia Biblioteca economică-seria Probleme economice vol.426,Academia Romana,Institutul national de Cercetari Economice "Costin C, Kiritescu"Bucuresti, 2014,

8. Cerna Silviu, Politica monetară, Editura Academiei Române, București,2014

9. Dragomir Georgeta. Structuri şi mecanisme financiar-monetare. Editura Universitară "Danubius" : Pro Universitaria, 2010

10. Catalin Davidescu,Supravegherea bancara.Studiu comparativ in tarile Uniunii Europene,Colectia Biblioteca economicăseria Probleme economice vol.429,Academia Romana,Institutul national de Cercetari Economice "Costin C,Kiritescu"Bucuresti,2014,

11. Stabilitate Financiara-BNR https://www.bnr.ro/Stabilitate-financiara---Rolul-BNR-3114.aspx

12. Legislatie bancara in vigoare: OU.99/2006; LG.227/2007; OU.50/2010;

13. Banca Nationala a Rmaniei- www.bnr.ro 